\title{
Response to Foliar Micronutrients Application: Oil Content, Fatty Acid Profiling, Growth and Yield Attributes in Sunflower Hybrids
}

Ayaz Mehmood ( $\sim$ ayaz.gill@uoh.edu.pk)

The University of Haripur

Junaid Ahmed

The University of Haripur

Shah Rukh

University of Peshawar

Khurram Shahzad

The University of Haripur

Mazhar Rafique

The University of Haripur

Muhammad Imran

Ghazi University

Ahmad Khan

Pir Mehr Ali Shah Arid Agriculture University

Abdul Qayyum

The University of Haripur

Waseem Ahmad

The University of Haripur

Ali Gurmani

The University of Haripur

Zahid Shah

Pir Mehr Ali Shah Arid Agriculture University

Fahad Alghabari

King Abdulaziz University

Gyuhwa Chung

Chonnam National University

\section{Research Article}

Keywords: oil content, linoleic acid, oleic acid, stearic acid, palmitic acid, micronutrients 
Posted Date: April 12th, 2021

DOl: https://doi.org/10.21203/rs.3.rs-394987/v1

License: (c) (i) This work is licensed under a Creative Commons Attribution 4.0 International License. Read Full License 


\section{Abstract}

Micronutrient deficiency is widespread in alkaline soils of Pakistan which ultimately affect the yield and quality of sunflower oil. The current study was designed to investigate the combined as well as the sole effect of micronutrient application on the growth and yield attributes, and fatty acids profiling of selected sunflower hybrids. A field trial was conducted in sub-humid climatic conditions and two sunflower hybrids (FMC-1 and Parsun-3) were grown at the University of Haripur's research farm. Micronutrients were applied through the foliar application at the start of the bud growing stage and before the flowering stage i.e., after 30 and 55 days of sowing. The application of micronutrients resulted in significant variation in agronomic parameters of sunflower hybrids. Molybdenum among the sole application and in combination treatments $Z n, B$, and Mo increased the growth traits of sunflower genotypes, while application of $\mathrm{Zn}$ and Mo (among sole application), and combination of $\mathrm{Zn}, \mathrm{B}$, and Mo increased the yield attributes. Oil content was highest in the combination of three micronutrients ( $Z n, B$, and Mo) application followed by the $\mathrm{Zn}$ and $\mathrm{B}$ application individually. Sole micronutrients application also increased oil contents in both hybrids. Zinc application resulted in an increase of unsaturated fatty acids and a decrease in saturated fatty acids, while the B increased the oleic acid and stearic acid content and decreased the linoleic acid and palmitic acid contents. Among the varieties, FMC-1 has significantly achieved a higher yield than the Parsun-3. It is concluded from the research that $\mathrm{Zn}$ application increased the beneficial (poly-and mono-unsaturated) fatty acids and decreased the harmful (saturated) fatty acids. Zinc application @ 2 kg ha1 is recommended for good quality oil production.

\section{Introduction}

The major oilseed crops of Pakistan are cotton, mustard, rapeseed, sunflower, and canola. Sunflower (Helianthus annuus L.) is one of the most important and world's $4^{\text {th }}$ largest oilseed crop (Oil World, 2019) which is grown on an area of 27 million hectares with a production of 52 million tonnes worldwide (Oil World, 2019). Domestic edible oil production during previous years was 0.431 million tonnes which contributed only $12 \%$ of the total edible oil availability that was 3.623 million tonnes in Pakistan for the years 2016 and 2017 (Govt. of Pakistan 2019). Sunflower is cultivated on a total area of 264 thousand acres with total oilseed production of 0.14 million tonnes and oil production of 54 thousand tonnes in Pakistan during 2018-19 (Govt. of Pakistan 2019). Among the top 10 countries, Pakistan is ranked as the $4^{\text {th }}$ largest edible oil importer in the world. As we know, the population is inversely proportional to resources, i.e. increase in population causes a decrease in edible oil. Pakistan is a developing nation and it spends 1.377 billion US \$ annually on the import of edible oil but during the past years in 2018-19 this demand was increased and Pakistan has spent 1.455 billion US\$ on its import making the situation quite alarming.

Micronutrients especially zinc ( $\mathrm{Zn}$ ), molybdenum (Mo) and boron (B) are considered as the most important limiting factor for crop production especially in alkaline-calcareous soils. Almost $30 \%$ of agricultural soils are Zn deficient (Babaeian et al. 2011). Zinc is required for hormone stimulation, chlorophyll formation, protein, lipid metabolism, synthesis of carbohydrate, and enzymatic activity 
(Thenua et al. 2014). Zinc is also important in tryptophan biosynthesis (Oosterhuis et al. 1991), photosynthesis, synthesizing RNA and DNA and biomass production (Kobraee et al. 2011). Low Zn solubility in soils is the reason for its deficiency in plants, so Zn applied in small amounts by foliar application significantly increases crop yield (Sarkar et al. 2007). Zinc reduces the oxidation of membrane lipids and protein. The ionic form of $\mathrm{Zn}$ interferes with the generation and peroxidative attack of oxygen radicals produced in a membrane environment and metals redox cycling in membrane binding sites (Girotti et al. 1985). Molybdenum is an essential microelement and Mo soil content ranges between 0.01 and $17 \mathrm{mg} \mathrm{kg}^{1}$ (Kabata-Pendias 2011). Molybdenum is required for more than sixty enzymes catalyzing various redox reactions in crop plant metabolism (Zimmer and Mendel 1999). Molybdenum is a constituent of nitrate reductase and nitrogenase which is used for nitrate assimilation. Boron is essential for the development of buds, root tips and new leaf (Rerkasem 1996). Boron is involved in the regulation of metabolic activities and its deficiency affects the yield of crop plants. In field conditions, factors like alkalinity and calcareousness influence the uptake of the micronutrient's thus foliar fertilization can get considerable importance. Foliar application has the advantage of overcoming the negative effect of stress influencing root growth and nutrients absorption capacity. Previous studies have shown that even a minor quantity of nutrients, like $\mathrm{Zn}, \mathrm{Fe}, \mathrm{B}$, and $\mathrm{Mn}$ applied by foliar spraying increases the yield of oilseed crops significantly (Sarkar et al. 2007; Wissuwa et al. 2008).

The oil content and its composition such as saturated fatty acids (stearic and palmitic) and unsaturated fatty acids (oleic, linoleic and linolenic) are responsible for the quality of the sunflower oil. Fatty acids composition of oilseed crops is a quantitative trait that is supposed to be affected by $\mathrm{Zn}, \mathrm{B}$ and Mo deficiencies and toxicities (Ahmed et al. 2010; Skarpa et al. 2013; Bellaloui et al. 2013; Mehmood et al. 2018; Hamurcu et al. 2019). Micronutrient deficiencies reduce crop productivity as well as oil quality. Mostly, researches were carried out on the agronomic and yield attributes of the oilseed crops. In previous studies, the effect of a single micronutrient fertilizer on the crop yield and/or on oil quality attributes of oilseed crops was discussed whereas few have focused on the role of the combined applications of micronutrients in improving the growth and yield. The present study was designed to evaluate the combined as well as the sole effect of micronutrient application on the agronomic and yield attributes, and fatty acids profiling for oil quality of selected sunflower hybrids.

\section{Materials And Methods}

\subsection{Site Description and Experimental Layout}

A field trial was conducted at the agriculture research farm of The University of Haripur, Pakistan. The efficiency of the sole, as well as the combined application of micronutrients to achieve maximum seed yield, yield components and fatty acid profiling (oil quality parameters) under sub-humid climatic conditions on two sunflower hybrids (FMC-1 and Parsun-3), was observed. Foliar application of micronutrient was done at the start of the bud growing stage and before the flowering stage i.e. after 30 and 55 days of sowing. The rate of micronutrients application was Zn@ $2.0 \mathrm{~kg} \mathrm{ha}^{-1}, \mathrm{~B} @ 0.5 \mathrm{~kg} \mathrm{ha}^{-1}$ and Mo @ $7.5 \mathrm{~kg} \mathrm{ha}^{-1}$. The experiment was executed in RCBD with three replications. Recommended doses of 
nitrogen $\left(120 \mathrm{~kg} \mathrm{ha}^{-1}\right)$, phosphorous $\left(60 \mathrm{~kg} \mathrm{ha}^{-1}\right)$ and potassium $\left(60 \mathrm{~kg} \mathrm{ha}^{-1}\right)$ were applied using urea, diammonium phosphate, and murate of potash fertilizers. The full dose of phosphate and potash fertilizers and half dose of nitrogenous fertilizer was incorporated the sowing time while half nitrogenous fertilizer was applied when the plants attained 4-5 leaf stage. Seventy-five $\mathrm{cm}$ row to row distance and twenty-five $\mathrm{cm}$ plant to plant distance was maintained. The net plot size was $(1.35 \mathrm{~m} \times 5$ $\mathrm{m})$, and sowing was done using dibbler by putting two seeds per hole. When the crop was at the 2-3 leaf stage, thinning was carried out. The following parameters were recorded during the experiment.

\subsection{Soil Analyses}

Soil electrical conductivity (EC) was determined by 1:1 soil water suspension (Richard 1954). The soil suspension was made by $25 \mathrm{~g}$ soil and $25 \mathrm{~mL}$ deionized water in a $100 \mathrm{~mL}$ beaker. Then the suspension was mixed for 2 minutes using a glass rod. Soil EC was recorded using a calibrated EC meter after 30 minutes. The soil pH from the same suspension was also measured (Thomas et al. 1966). Soil organic matter was measured by organic carbon reduction using potassium dichromate and titrating against ferrous ammonium sulfate following Nelson and Sommers (1982) method. Soil textural class was determined by the hydrometer method which obeys Stokes Law (Gee and Bauder 1986).

\subsection{Agronomic and Yield Parameters}

At the time of the vegetative growth period completion, the number of leaves per plant was counted, and plant height was measured using measuring tape by selecting two rows in the center of each plot. Randomly 10 plants were selected, and the head diameter of sunflower was measured using Vernier caliper. Randomly 10 plants were selected at physiological maturity and their stem girth was measured using the Vernier caliper. Weight per head, numbers of achenes per head and achene yield per hectare was calculated after harvesting as yield parameters.

\subsection{Oil Content and Fatty Acids Profiling}

Sunflower heads were harvested after the physiological maturity stage. Oil content and fatty acids levels (stearic, palmitic, linoleic and oleic) in the seed were determined. Oil content was measured by the Soxhlet method based on the Nuclear magnetic resonance (NMR) extraction achenes in a continuous flow extractor (Granlund and Zimmerman 1975). The fatty acids level was determined as methyl esters using Shimadzu Gas-Liquid Chromatography (Stefanoudaki et al. 1999).

\subsection{Statistical Analysis}

Agronomic, yield and quality parameters were quantified and analyzed for variability using analysis of variance (ANOVA) by split-plot design by taking hybrids in the main plot and micronutrient treatments in the subplot. Treatments mean and hybrids mean were compared using the least significant difference (LSD) test (Steel et al. 1997). 


\section{Results}

The soil of the research field had no salinity problem but was low in organic matter $(0.90 \%)$ and plantavailable $\mathrm{P}\left(4.8 \mathrm{mg} \mathrm{kg}^{-1}\right)$ content. The soil $\mathrm{pH}$ was 7.90 , and the soil texture was classified as silt loam. The effect of micronutrient application on growth, yield, oil content, and fatty acid profiling as a sole as well as in combination with two sunflower hybrids are presented below.

\subsection{Growth Parameters}

Growth parameters of sunflower hybrids i.e. the number of leaves per plant, plant height $(\mathrm{cm})$, stem girth $(\mathrm{cm})$ and head diameter $(\mathrm{cm})$ were measured at the end of the physiological maturity stage. The number of leaves per plant was nonsignificant with hybrids $(p \geq 0.0026)$ while varied significantly with micronutrients application ( $p \geq 0.0001)$. The number of leaves per plant, when averaged over the treatments, was higher in Parsun-3 than FMC-1 (Table 1). Plant height, stem girth, and head diameter varied significantly with sunflower hybrids and micronutrient treatments (Table 1). Overall, FMC-1 performed better than the Parsun-3 in all the growth parameters. Among the combinations treatments, the combination of three $(\mathrm{Zn}+\mathrm{B}+\mathrm{Mo})$ micronutrients gave the highest result in all the growth parameters while among the sole application, the highest growth parameters were observed for Mo followed by $\mathrm{Zn}$ and $\mathrm{B}$.

\subsection{Yield Parameters}

Yield parameters of sunflower hybrids (weight of the head, no. of achenes head ${ }^{-1}$, the weight of thousand achenes and achene yield) with micronutrients application are presented in Table 2. Yield parameters significantly varied with sunflower hybrids and micronutrients application. Among sunflower hybrids, FMC-1 performed better than Parsun-3 in yield parameters including head weight, no. of achenes head ${ }^{-1}$, the weight of thousand achenes and achene yield. Among the micronutrient treatments, the combination of $\mathrm{Zn}, \mathrm{B}$, and Mo was observed best in the yield parameters while the sole application of $\mathrm{Zn}$ and Mo performed better than B. Achene yield varied significantly with sunflower hybrids $(p \geq 0.0018)$ and micronutrients application $(p \geq 0.0001)$. Achene yield, when averaged over the treatments were higher in FMC-1 (3761) than Parsun-3 (3455) (Table 2). Achene yield was maximum in the combination of three micronutrients $(\mathrm{Zn}+\mathrm{B}+\mathrm{Mo})$. Among the sole application of micronutrient, achene yield was highest in $\mathrm{Zn}$ followed by Mo and B application.

Table 1. Mean growth parameters variations in sunflower Hybrids and micronutrients treatments 


\begin{tabular}{|c|c|c|c|c|}
\hline Factors & No. of leaves & Plant height & Stem girth & Head diameter \\
\hline Hybrids & & $-15.78 \mathrm{a}$ & $17.66 \mathrm{a}$ \\
\hline FMC-1 & $27.77 \mathrm{a}$ & $225 \mathrm{a}$ & $5.78 \mathrm{-}$ & $16.48 \mathrm{~b}$ \\
\hline Parsun-3 & $28.23 \mathrm{a}$ & $159 \mathrm{~b}$ & $5.20 \mathrm{~b}$ & \\
\hline Treatments & & & & $15.65 \mathrm{~h}$ \\
\hline Control & $25.43 \mathrm{~h}$ & $172 \mathrm{~h}$ & $4.71 \mathrm{~h}$ & $16.73 \mathrm{f}$ \\
\hline Zn & $26.99 \mathrm{f}$ & $184 \mathrm{f}$ & $4.96 \mathrm{~g}$ & $15.97 \mathrm{~g}$ \\
\hline B & $26.26 \mathrm{~g}$ & $177 \mathrm{~g}$ & $5.13 \mathrm{f}$ & $17.37 \mathrm{e}$ \\
\hline Mo & $27.70 \mathrm{e}$ & $193 \mathrm{~d}$ & $5.30 \mathrm{e}$ & $17.40 \mathrm{~d}$ \\
\hline Zn+B & $28.18 \mathrm{~d}$ & $190 \mathrm{e}$ & $5.61 \mathrm{~d}$ & $17.74 \mathrm{~b}$ \\
\hline Zn+Mo & $29.73 \mathrm{~b}$ & $205 \mathrm{~b}$ & $5.81 \mathrm{c}$ & $17.55 \mathrm{c}$ \\
\hline Mo+B & $28.85 \mathrm{c}$ & $200 \mathrm{c}$ & $6.10 \mathrm{~b}$ & $18.17 \mathrm{a}$ \\
\hline Zn+B+Mo & $30.85 \mathrm{a}$ & $210 \mathrm{a}$ & $6.27 \mathrm{a}$ & \\
\hline
\end{tabular}

The mean sharing the same letters are statistically similar $(p>0.05)$. The number of means for sunflower hybrids is 24 and treatments are 6.

Table 2. Mean yield parameters variations in sunflower hybrids and micronutrients treatments

\begin{tabular}{|c|c|c|c|c|}
\hline Factors & Weight of Head & No. achenes head & 1000 achenes weight & Achene yield \\
\hline Hybrids & $\mathrm{g}$ & & $\mathrm{g}$ & $\mathrm{kg} \mathrm{ha}^{-1}$ \\
\hline FMC-1 & $203 \mathrm{a}$ & $1311 \mathrm{a}$ & $49.54 \mathrm{a}$ & $3761 \mathrm{a}$ \\
\hline Parsun-3 & $164 \mathrm{~b}$ & $1105 \mathrm{~b}$ & $46.33 \mathrm{~b}$ & $3455 \mathrm{~b}$ \\
\hline Treatments & & & & \\
\hline Control & $124 \mathrm{~g}$ & $1131 \mathrm{~h}$ & $44.66 \mathrm{e}$ & $3362 \mathrm{~h}$ \\
\hline Zn & $200 \mathrm{c}$ & $1207 \mathrm{~d}$ & $47.66 \mathrm{bc}$ & $3600 \mathrm{~d}$ \\
\hline B & $145 \mathrm{f}$ & $1158 \mathrm{~g}$ & $46.16 \mathrm{~d}$ & $3462 \mathrm{~g}$ \\
\hline Mo & $191 \mathrm{e}$ & $1180 \mathrm{f}$ & $47.25 \mathrm{~cd}$ & $3530 \mathrm{f}$ \\
\hline Zn+B & $201 \mathrm{c}$ & $1225 \mathrm{c}$ & $48.83 \mathrm{~b}$ & $3710 \mathrm{c}$ \\
\hline Zn+Mo & $205 \mathrm{~b}$ & $1257 \mathrm{~b}$ & $50.33 \mathrm{a}$ & $3743 \mathrm{~b}$ \\
\hline Mo+B & $193 \mathrm{~d}$ & $1205 \mathrm{e}$ & $47.83 \mathrm{bc}$ & $3583 \mathrm{e}$ \\
\hline Zn+B+Mo & $211 \mathrm{a}$ & $1297 \mathrm{a}$ & $50.83 \mathrm{a}$ & $3879 \mathrm{a}$ \\
\hline
\end{tabular}


The mean sharing the same letters are statistically similar $(p>0.05)$. The number of means for sunflower hybrids is 24 and treatments are 6.

\subsection{Oil Content and Fatty Acids Profiling}

Quantitative measurements of oil contents and fatty acids (linoleic acid, oleic acid, palmitic acid, and stearic acid) in sunflower hybrids with micronutrient applications are carried out. The oil content of sunflower seed was nonsignificant with hybrids while it differed significantly with micronutrients application ( $p \geq 0.0001)$. Overall the oil contents, when averaged over the treatments, were similar in both of the hybrids (Table 3). Oil content, when averaged over the hybrids, was significantly different due to the micronutrient application (Table 3). Oil content was highest in the combination of three micronutrients $(\mathrm{Zn}+\mathrm{B}+\mathrm{Mo})$ application followed by the $\mathrm{Zn}$ and $\mathrm{B}$ application. The variation in oil content differed significantly with micronutrient treatments as the hybrid*treatments interaction was significant $(p \geq$ 0.007). Sole micronutrients application also increased oil contents in both hybrids (Figure 1).

Linoleic acid is an unsaturated fatty acid that was nonsignificant with sunflower hybrids and varied significantly with micronutrients application ( $p \geq 0.0001)$. Linoleic acid contents, when averaged over the treatments, were higher in FMC-1 (72.89 \%) than Parsun-3 (71.10 \%) (Table 3). Linoleic acid was highest in the combination of three micronutrients $(Z n+B+M o)$ application followed by the $Z n+M o$ combination. Among the sole application of micronutrient, the highest linoleic acid content was in the $\mathrm{Zn}$ application followed by Mo. In contrast, B application reduced the linoleic acid compares to the control treatment (Figure 2). Linoleic acid variation differed significantly with micronutrient treatments as the hybrids*treatments interaction was significant. Among all the treatments, $\mathrm{Zn}+\mathrm{B}+\mathrm{Mo}, \mathrm{Zn}+\mathrm{Mo}$ and sole application of $\mathrm{Zn}$ were statistically similar and higher than other treatments in both hybrids. When the micronutrients were applied in combination the highest linoleic acid contents were recorded in the $\mathrm{Zn}+\mathrm{B}+$ Mo treatment.

Table 3. Mean oil contents and fatty acids variations in sunflower hybrids and micronutrients treatments 


\begin{tabular}{|c|c|c|c|c|c|}
\hline Factors & Oil contents & Linoleic acid & Oleic acid & Palmitic acid & Stearic acid \\
\hline Hybrids & \multicolumn{5}{|c|}{$\%$} \\
\hline FMC-1 & $38.10 \mathrm{a}$ & $72.89 \mathrm{a}$ & $14.54 \mathrm{~b}$ & $6.93 \mathrm{a}$ & $6.24 \mathrm{~b}$ \\
\hline Parsun-3 & $38.55 \mathrm{a}$ & $71.10 \mathrm{a}$ & $15.99 \mathrm{a}$ & $5.84 \mathrm{~b}$ & $7.15 \mathrm{a}$ \\
\hline Treatments & & & & & \\
\hline Control & $37.07 \mathrm{f}$ & $71.00 \mathrm{f}$ & $14.72 \mathrm{f}$ & $7.04 \mathrm{~b}$ & $7.01 \mathrm{c}$ \\
\hline Zn & $38.31 \mathrm{c}$ & $73.13 \mathrm{c}$ & $15.20 \mathrm{~d}$ & $5.66 \mathrm{e}$ & $5.91 \mathrm{~g}$ \\
\hline B & $37.88 \mathrm{~d}$ & $70.12 \mathrm{~g}$ & $15.33 \mathrm{c}$ & $6.95 \mathrm{c}$ & $7.44 \mathrm{a}$ \\
\hline Mo & $37.37 \mathrm{e}$ & $71.25 \mathrm{e}$ & $14.92 \mathrm{e}$ & $7.14 \mathrm{a}$ & $7.14 \mathrm{~b}$ \\
\hline Zn+B & $39.11 \mathrm{~b}$ & $72.08 \mathrm{~d}$ & $15.51 \mathrm{~b}$ & $5.85 \mathrm{~d}$ & $6.54 \mathrm{~d}$ \\
\hline Zn+Mo & $38.41 \mathrm{c}$ & $73.44 \mathrm{~b}$ & $15.46 \mathrm{~b}$ & $5.64 \mathrm{e}$ & $6.02 \mathrm{f}$ \\
\hline Mo+B & $38.27 \mathrm{c}$ & $71.31 \mathrm{e}$ & $15.37 \mathrm{c}$ & $6.96 \mathrm{c}$ & $7.13 \mathrm{~b}$ \\
\hline Zn+B+Mo & $40.18 \mathrm{a}$ & $73.62 \mathrm{a}$ & $15.62 \mathrm{a}$ & $5.84 \mathrm{~d}$ & $6.41 \mathrm{e}$ \\
\hline
\end{tabular}

The mean sharing the same letters are statistically similar $(p>0.05)$. The number of means for sunflower hybrids is 24 and treatments are 6.

Oleic acid is also an unsaturated fatty acid and varied significantly with sunflower hybrids $(p \geq 0.027)$ and micronutrients application ( $p \geq 0.0001)$. Oleic acid contents were higher in Parsun-3 $(15.99 \%)$ than FMC-1 (14.54 \%) (Table 3). Oleic acid was highest in the combination of three micronutrients ( $\mathrm{n} n+\mathrm{B}+\mathrm{Mo})$. Among the sole application of micronutrient, the highest oleic acid content was in B application followed by $\mathrm{Zn}$ and Mo. Variation in oleic acid also differed significantly with micronutrient treatments as the hybrid*treatments interaction was significant. Boron application increased the oleic acid content followed by $\mathrm{Zn}$ and Mo application in both genotypes (Figure 3). Among all the treatments, three micronutrient combinations, and $\mathrm{Zn}$ and $\mathrm{B}$ sole application was statistically similar and higher than other treatments in both hybrids.

Palmitic acid is saturated fatty acid, when averaged over the treatments, were higher in FMC-1 $(6.93 \%)$ than Parsun-3 (5.84 \%) (Table 3). Zinc and B application decreased the palmitic acid while Mo application increased the palmitic acid contents. Variation in palmitic acid also differed significantly with micronutrient treatments as the hybrid*treatments interaction was nonsignificant. Zinc application decreased the palmitic acid contents followed by $B$ while Mo increased the palmitic acid contents in both of genotypes (Figure 4).

Stearic acid is also a saturated fatty acid was significantly varied with the micronutrient application (Table 3). Zinc application decreased while B and Mo application increased the stearic acid contents. Stearic acid variation also differed significantly with micronutrient treatments as the hybrid*treatments 
interaction was nonsignificant. Application of $\mathrm{Zn}$ resulted in decreased stearic acid contents while $\mathrm{B}$ and Mo application showed an increase in stearic acid contents (Figure 5).

\section{Discussion}

The variation in growth parameters of sunflower hybrids growing in identical field environments may be related to their genetic makeup. Better performance in growth parameters by Mo application may enhance macronutrient bioavailability especially nitrogen, as Mo is a constituent of nitrate reductase and nitrogenase and required for nitrate assimilation (Skarpa et al. 2013). Foliar application of Mo and calcium increased the nitrogen content of poinsettia (Ayala-Arreola et al. 2008). Silva et al. (2012) also reported an increase in nitrogen bioavailability to bean leaves due to the application of micronutrients. Molybdenum is very important role in plant growth and its metabolism in the form of enzymes, including sulfite oxidase, nitrate reductase, aldehyde oxidase, xanthine dehydrogenase, and the mitochondrial amidoxime reductase (Havemeyer et al. 2006; Mendel 2011; Mendel and Kruse 2012). Molybednum has both structural and catalytic functions in these enzymes and also directly involved in redox reactions and in sulfite detoxification, nitrate assimilation, purine degradation and abscisic acid synthesis (Mendel 2011).

The variation in yield parameters by the sunflower hybrids might be ascribed to the genetic difference among the respective hybrids (Iqbal 2017). Zinc is involved in the biosynthesis of auxin; it also accelerates photosynthetic activity by enhnsing carbonic anhydrase (Ohki 1976; Welch 1995). Increased photosynthetic activity, in turn, enhances the yield in crop plants (Wang et al. 1985; Kler et al. 1989). Mirzapour and Khoshgoftar (2006) reported that the addition of $20 \mathrm{~kg} Z \mathrm{n}$ per hectare increased the yield of sunflower statistically. The micronutrients application on the growth of sunflower, in terms of dry matter, seed yield, leaf area index, leaf area duration, net assimilation rate and crop growth rate and can be interpreted in terms of the metabolic function of micronutrients in the plant (Amberger, 1980). Application of $\mathrm{Zn}$ in combination with B exhibited yield increase over unfertilized soils (2005). Application of Mo increased the common beans yield (Lima et al. 1999), similarly, various studies reported an increase in yield of oilseed crops attributed to Mo application (Valentini et al. 2005; Zoz et al. 2012; Skarpa et al. 2013). Molybdenum application on increasing achene yield is associated with an increased ability of the plant to utilize nitrogen. Biscaro et al (2011) also boserved that $\mathrm{N}$ fertilization increased grain yield only when combined with Mo foliar supply. Molybdenum is a component of the many enzymes as discussed earlier. Due to Mo role in $\mathrm{NO}_{3}$ assimilation, nitrogen fixation processes, and transport of nitrogen compounds in plants, Mo plays a very important role in the metabolism of nitrogen in crop plants (Li et al. 2013). An increase in seed yield in oilseed rape cultivars was observed with the application of $0.75 \mathrm{~kg}$ hexaammonium heptamolybdate tetrahydrate per hectare as Mo source (Qin et al. 2015).

The increase in the oil content of sunflower seeds with Zn application may be due to a higher assimilate supply (Khurana and Chatterjee 2001). The increase in oil content was higher with Zn application than B and Mo applications. Similar results were recorded by Sawan et al. (2006) in the oil contents of cotton 
seeds with $\mathrm{Zn}$ application. The increase in oil content is due to increased total photosynthates and a more effective translocation of photoassimilates (Ohki 1976).

Zinc application reduced saturated fatty acids (stearic as well as palmitic acid) and increased the unsaturated fatty acids as reported by Sharifi (2016) for the soybean hybrids and by Ahmed et al. 2010 for the oilseed crops. An increase in unsaturated fatty acids with $\mathrm{Zn}$ application is also recorded by Zeng (1996), and Sawan et al. (2006) in oilseed crops. Zinc is required for biomembranes stability by interaction with phospholipids and sulfhydryl groups (Chvapil 1973; Sunamoto et al. 1980; von Glos and Boursnell 1981). Furthermore, as a metal component of superoxide dismutase, $\mathrm{Zn}$ is part of the system for scavenging superoxide radicals, oxygen ions, and thus required for the protection of the membranes from powerful oxidizing oxygen species such as the hydroxyl radical (Fridovich 1986). Stearic acid increase with Mo application in sunflower is also reported by Skarpa et al. (2013). Hamurcu et al. (2019) also reported similar results in fatty acids variation (an increase in oleic acids and stearic acid while a decrease in linoleic acid and palmitic acid) with B application. Boron application regulates the seed composition by influencing the fatty acid content and seed protein (Bellaloui et al. 2010). Boron is involved in enhancing the translocation of photoassimilates from vegetative to reproductive parts as it plays an important role in the translocation of sugars, which are reported having an incremental effect on metabolic activities (Reddy et al. 2003)

\section{Conclusion}

Conclusive evidence of increased oil content was observed in the combination of three micronutrients $(\mathrm{Zn}+\mathrm{B}+\mathrm{Mo})$ application followed by $\mathrm{Zn+B}$ application. Sole micronutrients application also increased oil contents in both varieties. Boron application increased the oleic acid and decreased the linoleic acid contents, whereas an increase in stearic acid was noticed. Zinc application increased beneficial fatty acids (mono- and polyunsaturated) while showed a reduction in harmful saturated fatty acids. Zinc application @ $2 \mathrm{~kg} \mathrm{ha}^{-1}$ is recommended for good quality oil production. Among the varieties, FMC-1 has a significantly higher yield than Parsun-3. We recommend FMC-1 for the cultivation in sub-humid climatic conditions with Zn application @ 2 kg per hectare and Mo @ 7.5 kg hectare as Mo in combination with Zn application increase the yield and yield-related parameters.

\section{Declarations}

\section{Funding}

This study didn't receive any specific funding from the company or institute.

\section{Conflict of Interest}

The authors declare that they have no conflict of interest.

\section{General Statement}


Seed were provided by Oilseeds Research Program, National Agriculture Research Centre, Pakistan. The study was conduted at Agriculture Research Farm, The University of Haripur.

\section{References}

1. Amberger A (1980). Foliar application of micronutrients, uptake and incorporation into metabolism. $2^{\text {nd }}$ Workshop 'Micronutrients and Plant Nutrition', Mariut, Egypt, 1979, NRC, Cairo, Egypt. pp. 47-60.

2. Ayala-Arreola J, Castillo-González AM, Valdez-Aguilar LA, Colinas-León MT, PinedaPineda J, AvitiaGarcía E (2008) Effect of calcium, boron and molybdenum on plant growth and bract pigmentation in poinsettia. Rev Fitotec Mex 31(2):165-172.

3. Ahmed N, Abid M, Rashid A (2010) Zinc fertilization impact on the irrigated cotton grown in an Aridisol: Growth, productivity, fiber quality, and oil quality. Commun Soil Sci Plant Anal 41(13):16271643.

4. Babaeian M, Tavassoli A, Ghambari A, Esmaeilian Y, Fahimifard M (2011) Effect of foliar micronutrient application on osmotic adjustment, grain yield and yield components in sunflower (Alstar cultivar) under water stress at three stages. Afr J Agri Res 6(5):1204-1208.

5. Bellaloui N, Hu Y, Mengistu A, Kassem MA, Abel CA (2013) Effects of foliar boon application on seed composition, cell wall boro, and seed $\delta 15 \mathrm{~N}$ and $\delta 13 \mathrm{C}$ isotopes in water-stressed soybean plants. Fron Plant Sci 4:270. https://doi.org/10.3389/fp/s.2013.00270

6. Bellaloui N, Reddy KN, Gillen AM, Abel CA (2010) Nitrogen metabolism and seed composition as influenced by foliar boron application in soybean. Plant and Soil 336(1-2):143-155.

7. Biscaro GA, Freitas-Junior NA, Soratto RP, Kikuti H, Goulart Junior SAR, Aguirre WM (2011). Nitrogênio em cobertura e molibdênio via foliar no feijoeiro irrigado cultivado em solo de Acta Sci Agron 33(4):665-670.

8. Chvapil M (1973) New aspects in the biological role of zinc: A stabilizer of macromolecules membranes. Life Sci 13(8):1041-1049.

9. Fridovich I (1986) Biological effects of the superoxide radical. Arch Biochem Biophys 15;247(1):1-11.

10. Gee GW, Bauder JW (1986) Particle size analysis. In: Klute A, editor. Methods of soil analysis, part 1. Madison (WI): Am Soc Agro p. 383-411.

11. Girotti AW, Thomas JP, Jordon JE (1985) Inhibitory effect of zinc (II) on free radical lipid peroxidation in erythrocyte membranes. Free Radicals in Biology \& Medicine 1(5-6):395-401.

12. Gitte AN, Patil SR, Tike MA (2005) Influence of zinc and boron on biochemical and yield characteristics of sunflower. Ind J. Plant Physiol 10:400-403.

13. Government of Pakistan (2019) Pakistan economic survey 2018-19. Ministry of Food, Agriculture and Livestock Division (Economic Wing), Islamabad, Pakistan. pp. 19-20.

14. Granlund M, Zimmerman DC (1975) Oil content of sunflower seeds as determined by wide-line nuclear magnetic resonance (NMR). Proc. ND Acad. Sci. 27. pp. 128-133. 
15. Hamurcu M Arsalan D, Hakki EE, Ozcan MM, Pandey A, Khan MK, Gezgin S (2019) Boron application affecting the yield and fatty acid composition of soybean genotypes. Plant Soil Environ 65(5):238243.

16. Havemeyer A, Bittner F, Wollers S, Mendel R, Kunze T, Clement B (2006). Identification of the missing component in the mitochondrial benzamidoxime prodrug-converting system as a novel molybdenum enzyme. J Biol Chem 281(46):34796-802.

17. Iqbal Q, Ali S, Shafique O, Tahir MN, Khan BA, Ahmad I, Khan I (2017)Assessment of different exotic sunflower hybrids for their agro-ecological adaptability. Pak J Agri Res 31(2):122-132.

18. Kabata-Pendias A, Pendia H (2011) Trace Elements in Soils and Plants. Boca Raton: CRC.

19. Khurana N, Chatterjee C (2001) Influence of variable zinc on yield, oil content, and physiology of sunflower. Commun Soil Sci Plant Anal 32(19-20):3023-3030.

20. Kler DS, Raj D, Dhillon, GS (1989). Modification of micro-environment with cotton canopy for reduced abscission and increased seed yield. Environ Ecol 7:800-802.

21. Kobraee S, Shamsi k, Rasekhi B (2011) Effect of micronutrients application on yield and yield components of soybean. Annal Biol Res 2(2):476-482.

22. Li SX, Wang ZH, Stewart BA (2013) Chapter five - responses of crop plants to ammonium and nitrate N Adv Agron 118. pp. 205-397

23. Lima SF, Andrade MJB, Carvalho JG (1999). Resposta do feijoeiro à adubação foliar de boro, molibdênio e Ciênc. Agrotecnol. 23:462-467.

24. Mehmood A, Saleem MF Tahir M, Sarwar MA, Abbas T, Zohaib A, Abbas HT (2018) Sunflower (Helianthus annuus) growth, yield and oil quality response to combined application of nitrogen and boron. Pak J Agr Res 31(1):86-97.

25. Mendel RR (2011) Cell biology of molybdenum in plants. Plant Cell Rep 30(10):1787-1797.

26. Mendel RR, Kruse T (2012) Cell biology of molybdenum in plants and humans. BBA-Mol Cell Res 1823(9): 1568-1579.

27. Mirzapour MH, Khoshgoftar AH (2006) Zinc application effects on yield and seed oil content of sunflower grown on a saline calcareous soil. J Plant Nutr 29(10):1719-1727.

28. Nelson DW, Sommers LE (1982) Total organic, organic matter 1. Methods of soil analysis, part 2. Chemical and microbiological properties. pp 539-579.

29. Ohki K (1976) Effect of zinc nutrition on photosynthesis and carbonic anhydrase activity in cotton. Physiologia Plantarum 38(4):300-304.

30. Oosterhuis D, Hake K, Bursmester C (1991) Foliar feeding cotton. Cotton Physiol Today 2:1-7.

31. Qin S, Sun X, Hu C, Tan Q, Zhuang G, Guo H(2015) Effects of molybdenum application on yield, Mo absorption and utilization in different rapeseed cultivars. Chinese J Oil Crop Sci 37(4):504-511.

32. Reddy NYA, Shaanker RU, Prasad TG, Kumar MU (2003) Physiological approaches to improving harvest index and productivity in sunflower. Helia 26(38):81-90. 
33. Rerkasem B (1996) Boron and plant reproductive development. Sterility in wheat in subtropical Asia: extent, causes and solutions. 72:32-34.

34. Richard LA (1954) Diagnosis and improvement of saline and alkali soils. 78(2):154. LWW.

35. Sarkar D, Mandal B, Kundu MC (2007) Increasing use efficiency of boron fertilizer by rescheduling the time and methods of application for crops in India. Plant and Soil 301(1-3):77-85.

36. Sawan Zm, Hafez SA, Basyony AE, Alkassas AR (2006) Cotttonseed, protein, oil yields and oil properties as affected by nitrogen fertilization and foliar application of potassium and plant growth retardant. World J Agric Sci 2(1):56-65.

37. Sharifi RS (2016) Application of biofertilizers and zinc increases yield, nodulation and unsaturated fatty acids of soybean. Zemdirbyste-Agriculture 103(3):251-258.

38. Silva WG, Carvalho JA, Oliveira EC, Rezende FC, Lima JJA, Rios GFA (2012). Manejo de irrigação para o feijão-de-metro, nas fases vegetativa e produtiva, em ambiente protegido. Revista Brasileira de Engenharia Agrícola e Ambiental 16 (9): 978-984.

39. Skarpa P, Kunzova E, Zukalova H (2013) Foliar fertilization with molybdenum in sunflower (Helianthus annuus). Plant Soil Environ 59(4): 156-161.

40. Steel RGD, Torrie JH, Dicky DA (1997) Principles and procedures of statistic. A Biometrical Approach, $3^{\text {rd }}$ McGraw-Hill Co Inc, New York, pp 400-428.

41. Stefanoudaki E, Kotsifaki F, Koutsaftakis A (1999) Classification of virgin olive oils of the tow major Cretan cultivars based on their fatty acid composition. J Am Oil Chem Soc 76(5):623-626.

42. Sunamoto J, Shironita M, Kawauchi N (1980) Liposomal membranes. V. Interaction of zinc (II) ion with egg phosphatidylcholine liposomes. Bull Chem Soc Jpn 53(10):2778-2781.

43. Thenua OVS, Singh K, Raj V, Singh J (2014) Effect of Sulphur and zinc application on growth and productivity of soybean (Glycine max. (L.) Merill) in northern plain zone of India. Ann Agri Res 35(2)183-187.

44. Thomas RE, Scwartz WA, Bendixen TW (1966) Soil chemical changes and infiltration rate reduction under sewage spreading. Soil Sci Soc Am J 30(5):641-646.

45. Oil World Annual (2019) Vol. 1. Global analysis of all major oilseeds, oils and oilmeals: Supply, demand and price outlook. ISTA Mielke Gmbh, May 2019.

46. Valentini L, Coelho FC, Ferreira MS (2005). Teor de nitrogênio foliar e produtividade de três cultivares de milho (Zea mays) submetidos à adubação nitrogenada e molíbdica. Rev Ceres 52(302):567-577.

47. von Glos KI, Boursnell JC (1981) Formation of a double salt of phosphatidylcholine and zinc chloride. Biochem J 193(3):1017-1019.

48. Wang JX, Chem WH, Yu YL (1985) The yield increasing effect of growth regulators on cotton and their application. China Cottons 3:32-33.

49. Welch RM (1995) Micronutrient nutrition of plants. Crit Rev Plant Sci 14(1):49-82.

50. Wissuwa M, Ismail AM, Graham RD (2008) Rice grain zinc concentrations as affected by genotype native soil-zinc availability, and zinc fertilization. Plant and Soil 306:37-48. 
51. Zeng Q (1996) Researches on the Effect of ZincApplied to Calcareous Soil in Cotton Field. China Cottons 23:21.

52. Zimmer W, Mendel R (1999) Molybdenum metabolism in plants. Plant Bio 1(2): 160-168.

53. Zoz T, Steiner F, Testa JVP, Seidel EP, Fey R, Castagnara DD, Zoz A (2012). Foliar fertilization with molybdenum in wheat. Semina: Ciênc Agric 33(2):633-638.

\section{Figures}

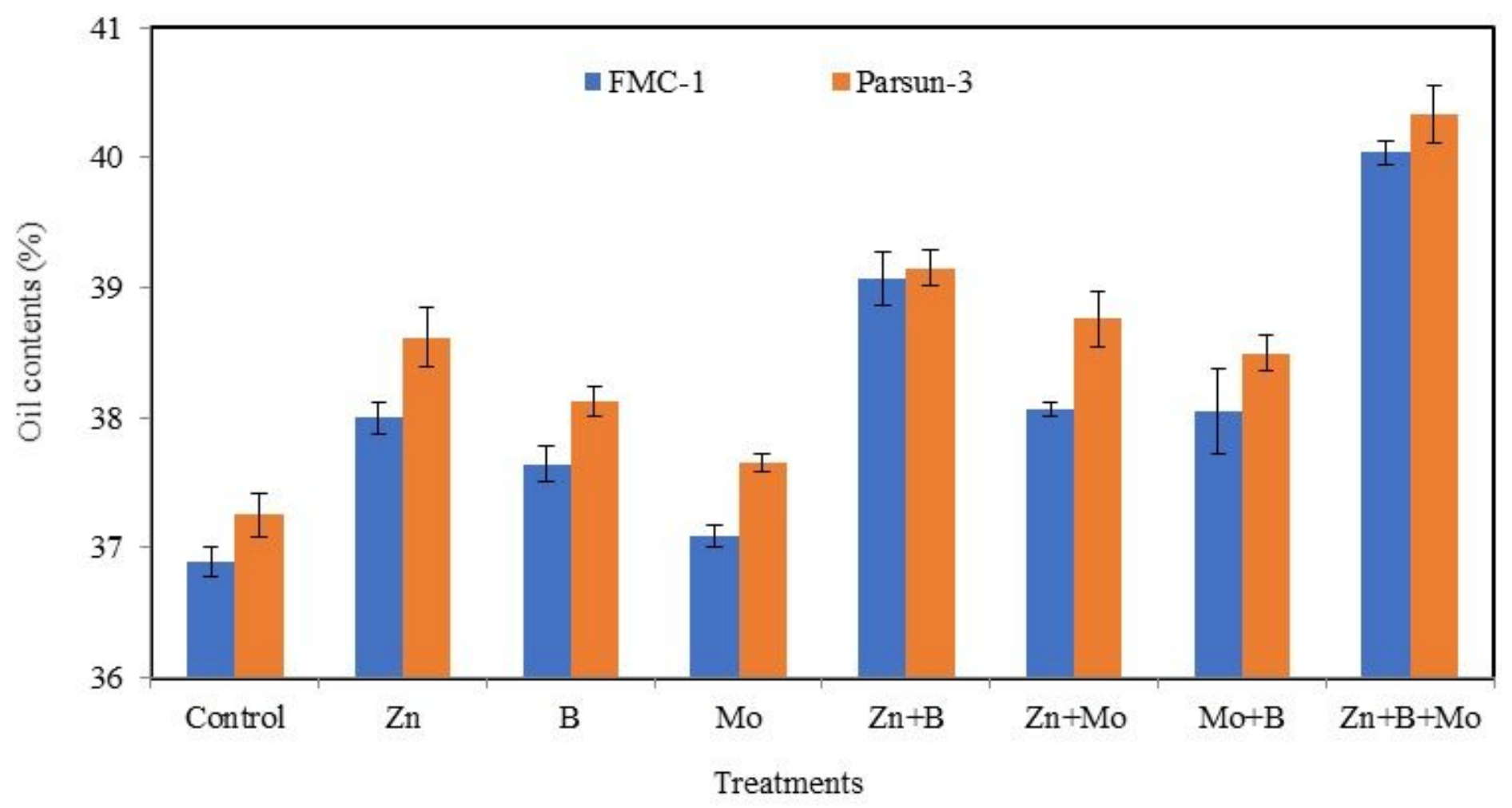

Figure 1

Effect of micronutrients application on oil contents in sunflower hybrids 


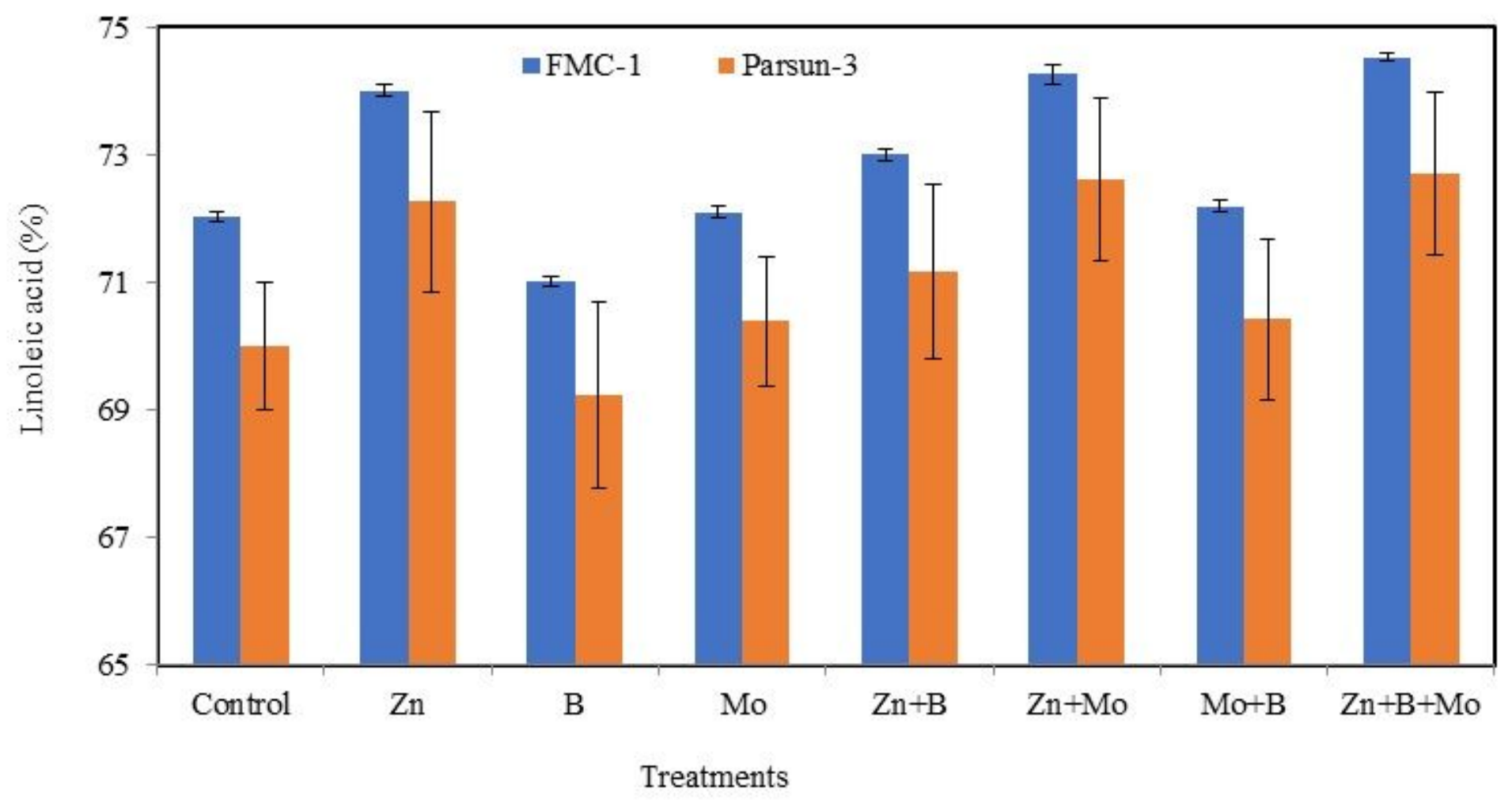

Figure 2

Effect of micronutrients application on linoleic acid contents in sunflower hybrids

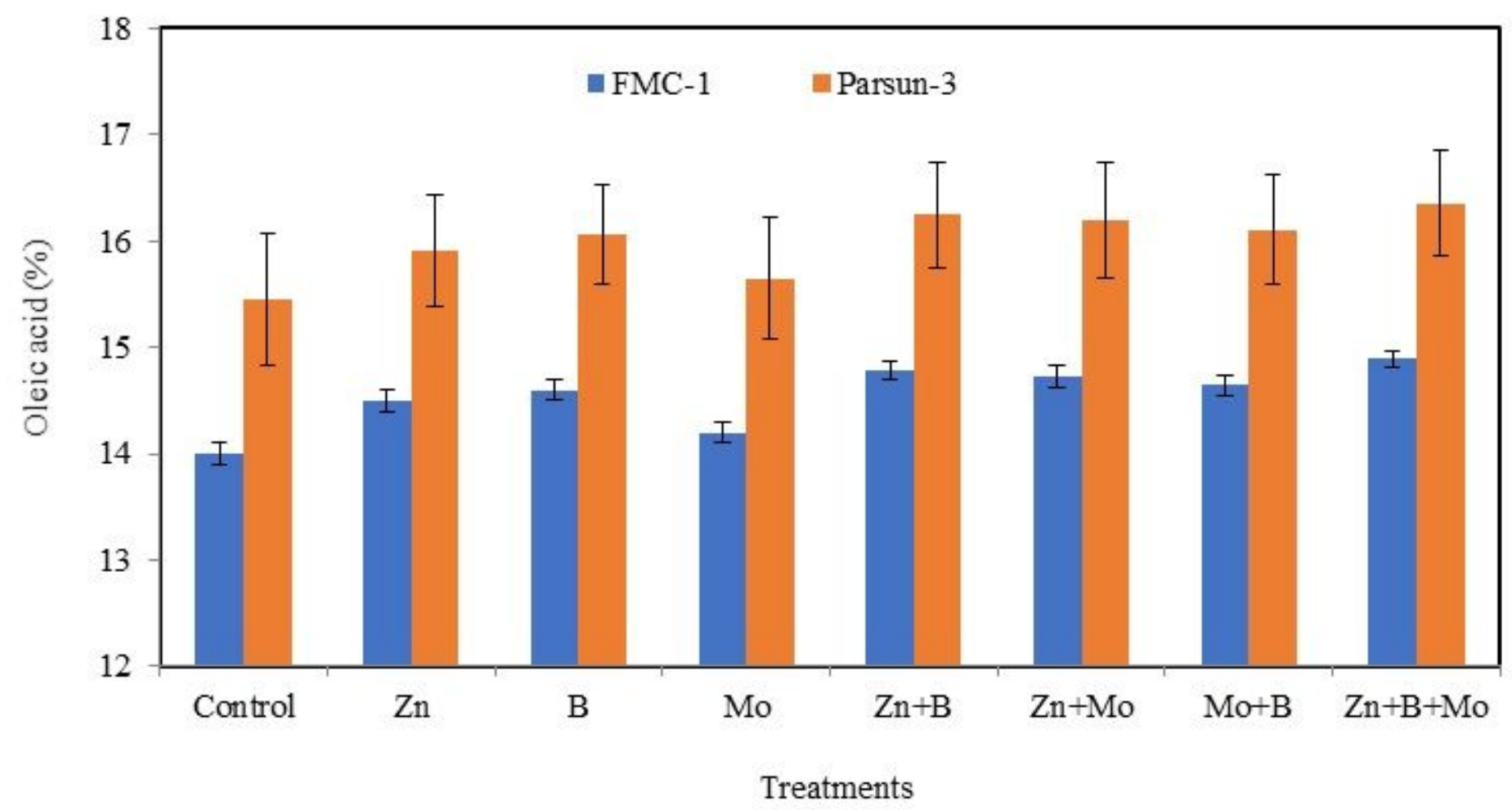

Figure 3 
Effect of micronutrients application on oleic acid contents in sunflower hybrids

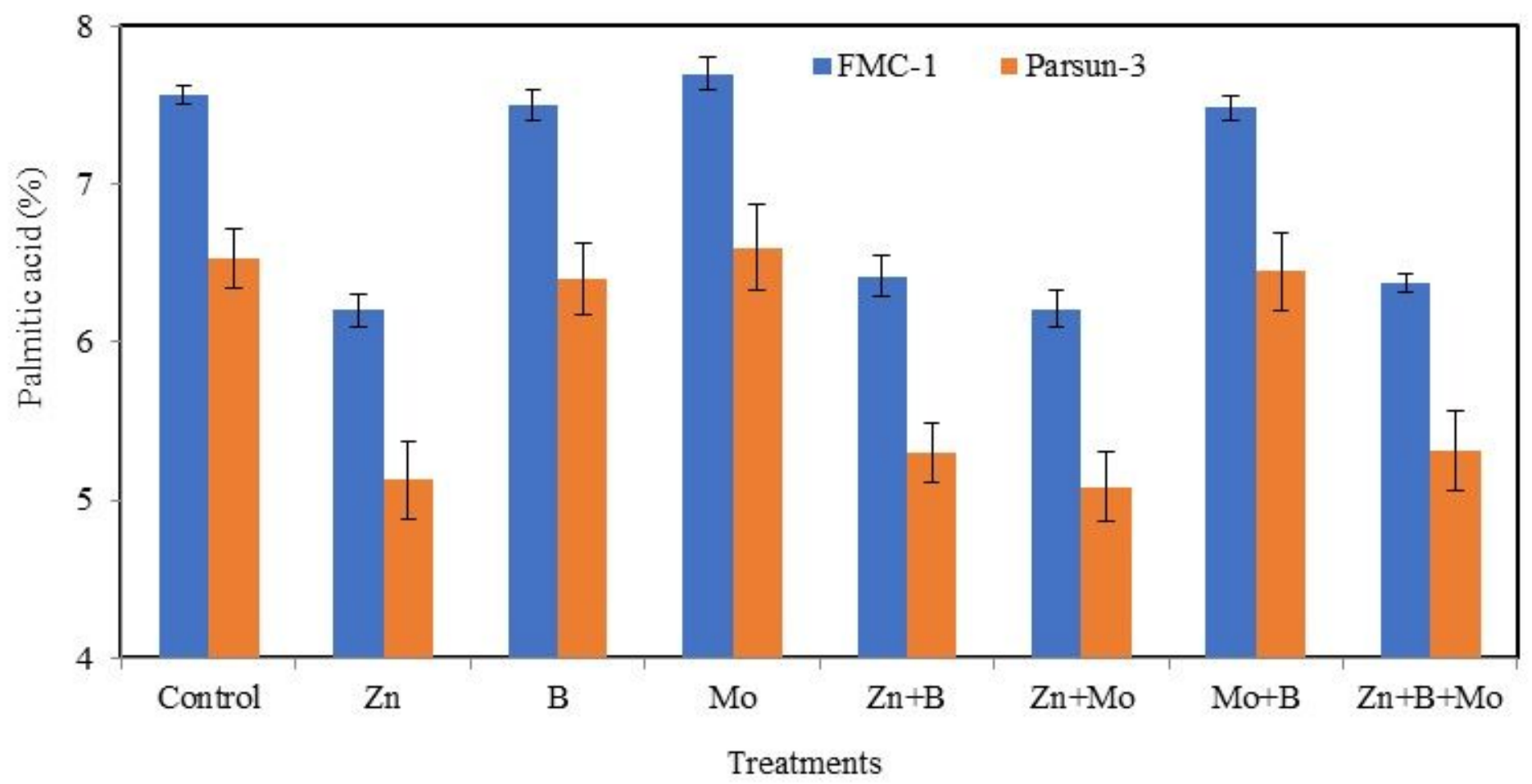

Figure 4

Effect of micronutrients application on palmitic acid contents in sunflower hybrids

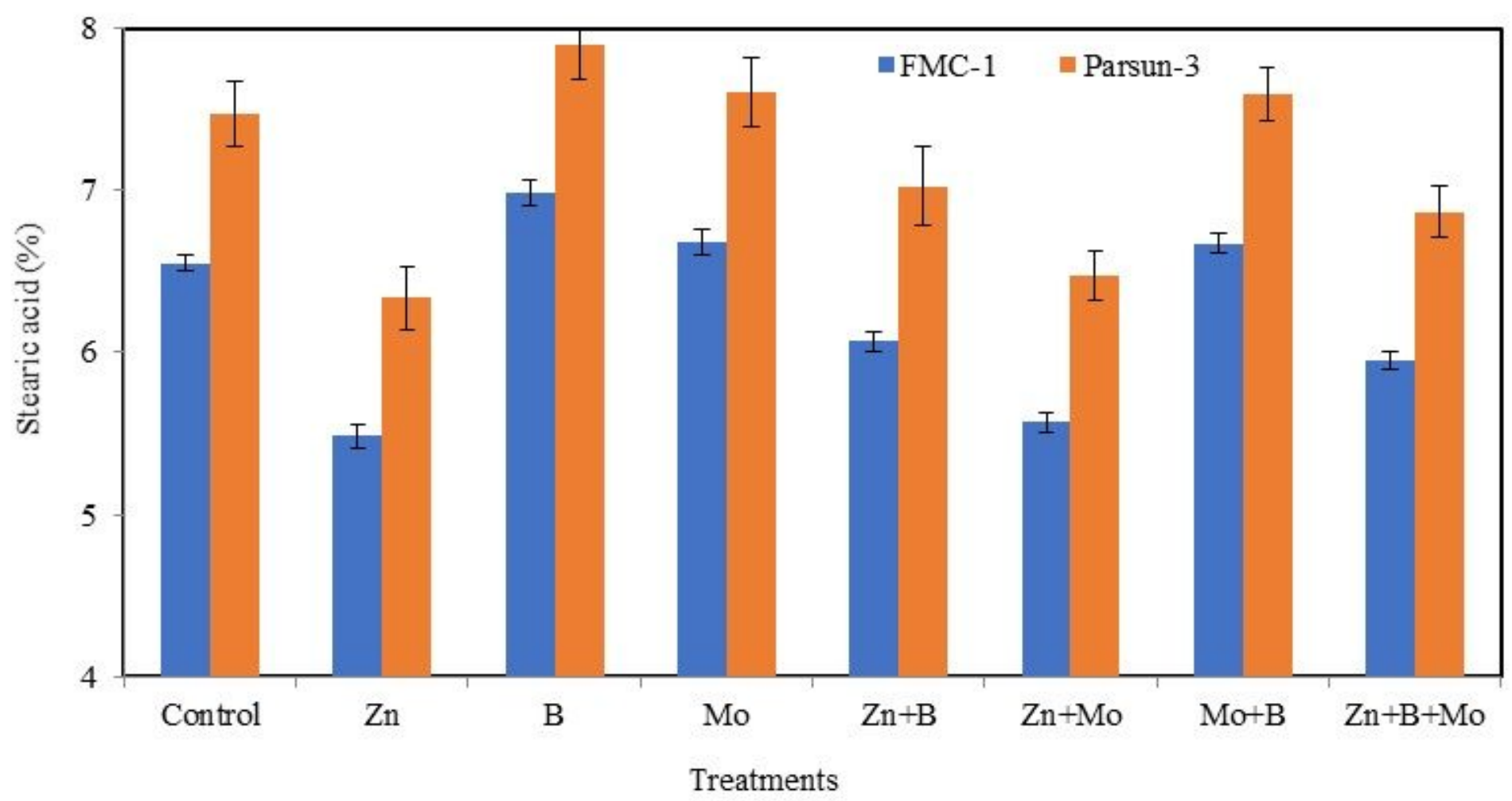

Figure 5 
Effect of micronutrients application on stearic acid contents in sunflower hybrids 